九州大学学術情報リポジトリ

Kyushu University Institutional Repository

\title{
Preparation of Protoplasts from Chlorella vulgaris K-73122 and Cell Wall Regeneration of Protoplasts from C. vulgaris K-73122 and C-27
}

Honjoh, Ken-ichi

Laboratory of Food Hygienic Chemistry, Division of Food Biotechnology, Department of

Bioscience and Biotechnology, Faculty of Agriculture, Graduate School, Kyushu University

Suga, Koushirou

Laboratory of Food Hygienic Chemistry, Division of Food Biotechnology, Department of Bioscience and Biotechnology, Faculty of Agriculture, Graduate School, Kyushu University

Shinohara, Fuminori

Laboratory of Food Hygienic Chemistry, Division of Food Biotechnology, Department of Bioscience and Biotechnology, Faculty of Agriculture, Graduate School, Kyushu University

Maruyama, Isao

Chlorella Industries Co. Ltd.

他

https://doi.org/10.5109/4494

出版情報：九州大学大学院農学研究院紀要. 47 (2)，pp. 257-266，2003-02-01. Faculty of Agriculture, Kyushu University

バージョン：

権利関係 : 


\title{
Preparation of Protoplasts from Chlorella vulgaris $\mathrm{K}-73122$ and Cell Wall Regeneration of Protoplasts from C. vulgaris $\mathrm{K}-73122$ and $\mathrm{C}-27$
}

\author{
Ken-ichi HONJOH', Koushirou SUGA,**, Fuminori SHINOHARA*, \\ Isao MARUYAMA**, Takahisa MIYAMOTO, Shoji HATANO*** \\ and Masayoshi IIO
}

\author{
Laboratory of Food Hygienic Chemistry, Division of Food Biotechnology, Department of Bioscience \\ and Biotechnology, Faculty of Agriculture, Graduate School, Kyushu University, \\ Fukuoka 812-8581, Japan \\ (Received October 28, 2002 and accepted November 7, 2002)
}

\begin{abstract}
Protoplasts from Chlorella vulgaris $\mathrm{K}-73122$ were obtained by enzymatic digestion with a mixture of Acromopeptidase, Cellulase ONOZUKA R-10, Chitosanase KI, Gluczyme, and Uskizyme. The formation of naked protoplasts was confirmed by fluorescence microscopy using fluorescent brightner 28 , which stains cell walls. About $88 \%$ of $C$. vulgaris $\mathrm{K}-73122$ cells were converted into osmotically-labile cells. Furthermore, a method for regeneration of intact cells from the protoplasts was developed. Utilization of $0.5 \mathrm{M}$ sucrose as an osmoticum, Fe-EDTA as an iron source, and bacto-agar as a supporting was shown to help regeneration of the cell walls of two strains, C. vulgaris $\mathrm{K}-73122$ and $\mathrm{C}-27$.
\end{abstract}

\section{INTRODUCTION}

Chlorella has served as one of the model organisms in physiological and biochemical studies of plants for a long time. In applied fields, it has been used in large quantity as health-promoting food for human as well as food for rotifers in cultivation fishery. Recently, Chlorella cell components were found to show several bioactivities such as antitumor activity (Noda et al., 1996) and high promotion activity of excretion of dioxins (Morita et al., 2001, 1999). The algae also have been used in biotechnology, for example, for production of useful proteins such as human-growth hormone and so on (Chen et al., 2001; Hawkins and Nakamura, 1999). Some species and strains of Chlorella have fast growth rates, which is favorable for industrial mass culture and this could be an additional advantage when the algae are used as materials for various purposes. In many aspects of utilization, however, the great drawback to Chlorella cells is that their cell walls are very rigid and are cumbersome barriers against utilization and breeding especially by genetic manipulation such as gene incorporation or cell fusion. Hence, protoplast formation from Chlorella cells as well as regeneration of the cell wall to restore the intact cells is a very

\footnotetext{
* Laboratory of Food Hygienic Chemistry, Division of Food Biotechnology, Department of Bioscience and Biotechnology, Graduate School of Bioresource and Bioenvironmental Sciences, Kyushu University, Fukuoka 812-8581, Japan

** Chlorella Industries Co. Ltd., 1343 Hisatomi, Chikugo, Fukuoka 833-0056, Japan

*** Graduate School of Health and Social Welfare Science, Nishikyushu University, 4490-9 Ooazaozaki, Kanzaki-machi, Kanzaki-gun, Saga 842-8585, Japan

+ Corresponding author (E-mail: honjoh@agr.kyushu-u.ac.jp)
} 
important technique to extensively utilize the algae.

So far, many investigations into the chemical composition of cell walls (Blumreisinger et al., 1983; Takeda, 1991, 1988; Takeda. and Hirokawa, 1984) and the preparation of protoplasts (Aach et al., 1978; Atkinson et al., 1972; Hatano et al., 1992; Yamada and Sakaguchi, 1981; Yamada et al., 1987) have been carried out with Chlorella. However, naked protoplasts from cells of only a few strains have been prepared (Hatano et al., 1992; Yamada and Sakaguchi, 1981; Yamada et al., 1987).

Our previous study showed that osmotically-labile $\mathrm{C}-27$ cells could be produced by treatment of cells with a mixture of chitosanase, mixed glycosidases, and homogenates from C-27 strain after a 3-h digestion (Hatano et al., 1992). Based on the report, we tried to prepare protoplasts of strain $\mathrm{K}-73122$ by enzymatic digestion with several commercially available enzymes. Furthermore, we tried to regenerate protoplast cells to intact cells of the strain and strain $\mathrm{C}-27$.

\section{MATERIALS AND METHODS}

\section{Culture of cells}

Cells of Chlorella vulgaris K-73122 were grown synchronously in Myers-4N medium (Watanabe, 1960), at $25^{\circ} \mathrm{C}$, under a photosynthetic photon flux density of $250 \mu \mathrm{mol} / \mathrm{m}^{2} \mathrm{~s}$, with $1.3 \% \mathrm{CO}_{2}$ in air, to a concentration of about $1.0 \times 10^{10}$ cells per liter, under a $20-\mathrm{h}$ light/4-h dark regime. C. vulgaris IAM C-27 was grown synchronously in MC medium under a 16-h light/8-h dark regime and other conditions were the same as those for K-73122 strain. Since cell walls of $C$. vulgaris C-27 were efficiently digested by cell-wall-digesting enzymes at the $\mathrm{L}_{2}$ stage (an intermediate stage during the ripening phase of the cell cycle; Hatano et al., 1976), cells of $C$. vulgaris $\mathrm{K}-73122$ at the $\mathrm{L}_{2}$ stage were used for protoplasts preparation.

\section{Preparation of homogenates of $C$. vulgaris $\mathrm{K}-73122$}

Homogenates containing the lytic enzymes were prepared from $C$. vulgaris $\mathrm{K}-73122$ as described below. Cells of $C$. vulgaris $\mathrm{K}-73122$ were collected at the $\mathrm{L}_{4}$ stage (the stage just before cell division; $18 \mathrm{~h}$ after the start of the cell cycle) by centrifugation at $2,000 \times \mathrm{g}$ for $5 \mathrm{~min}$ at $4^{\circ} \mathrm{C}$, washed twice with distilled water, and resuspended in distilled water (about $1.5 \times 10^{9} \mathrm{cell} / \mathrm{s} / \mathrm{ml}$ ). The suspension was homogenized with glass beads of $0.5 \mathrm{~mm}$ diameter in a reciprocal shaker (Vibrogen-Zellmühle; Edmund Bühler Co., Tübingen, Germany), operated at $4,500 \mathrm{rpm}$ for $20 \mathrm{~min}$ at $4^{\circ} \mathrm{C}$. The homogenate was freed from the glass beads by filtration on a sintered-glass funnel and centrifuged at $4,500 \times \mathrm{g}$ for $20 \mathrm{~min}$ at $4^{\circ} \mathrm{C}$. The supernatant was concentrated by lyophilization and used as the $C$. vulgaris $\mathrm{K}-73122$ homogenate.

\section{Preparation of homogenates of rotifer}

The rotifer homogenate containing the lytic enzyme was prepared as described below. Frozen rotifer (Brachionus rotundiformis obtained from Chlorella Industry Co. Ltd., Tokyo, Japan) was suspended in $50 \mathrm{mM}$ sodium phosphate buffer (pH 7.0) containing $1 \mathrm{mM}$ PMSF. The suspension was homogenized in a Waring Blender (Dynamics Corp. of America, New Hartford, CT, U.S.A.) for $3 \mathrm{~min}$. The homogenate was centrifuged 
at $4,500 \times \mathrm{g}$ for $20 \mathrm{~min}$ at $4^{\circ} \mathrm{C}$. Ammonium sulfate was added to $80 \%$ saturation and the mixture was kept in an ice bath for $1 \mathrm{~h}$. After centrifugation, the obtained pellet was dissolved in $5 \mathrm{ml}$ of $50 \mathrm{mM}$ sodium phosphate buffer ( $\mathrm{pH} 7.0$ ) with $1 \mathrm{mM}$ PMSF (phenylmethylsulfonylfluoride). The suspension was transferred to dialysis tube (cutoff 3,500: Nacalai Tesque, Kyoto, Japan) and dialyzed at $4{ }^{\circ} \mathrm{C}$ against $50 \mathrm{mM}$ sodium phosphate buffer ( $\mathrm{pH}$ 7.0) containing $1 \mathrm{mM}$ PMSF. The dialyzate was used as rotifer homogenate.

\section{Preparation of protoplasts from Chlorella cells}

For formation of protoplasts from $C$. vulgaris $\mathrm{K}-73122$, commercially available enzymes were obtained as follows: Acromopeptidase (Ac) and Cellulysine (Cl) were obtained from Wako Pure Chemical Ind. Ltd.; Cellulase ONOZUKA R-10 (Ce) and Macerozyme R-10 (Ma) were obtained from Yakult Pharmaceutical Ind. Co. Ltd.; Chitosanase (Ch), which is derived from Bacillus R-4 strain, was obtained K. I. Chemical Industry Co. Ltd.; Gluczyme (Gl) was obtained from Amano Enzyme Inc.; Pectinase (Pe) was obtained from Sigma Chemical Co.; Uskizyme (Us) was obtained from Kyowa Chemical Co.. Each preparation of the enzymes was dissolved in $25 \mathrm{mM}$ sodium phosphate buffer $(\mathrm{pH} 7.0)$ that contained $0.5 \mathrm{M}$ mannitol and the final concentrations of the digestive enzymes used were $4.0 \%(\mathrm{w} / \mathrm{v})$ for Ce and $1.0 \%(\mathrm{w} / \mathrm{v})$ for the others. When the rotifer homogenate was used by mixing with the other enzymes, $25 \mathrm{mM}$ sodium phosphate buffer ( $\mathrm{pH} 7.0$ ) with $1 \mathrm{M}$ mannitol was used for dissolution of the enzymes. The enzymes were dissolved individually or in combination in the digestion buffer, centrifuged $20,000 \times$ $\mathrm{g}$ for $20 \mathrm{sec}$ to remove insoluble matters, and then sterilized through polysulfone filters with a $0.45 \mu \mathrm{m}$ pore size (EB-DISK 25, Kanto Chemical Co., Inc.). Cells were collected at the $\mathrm{L}_{2}$ stage by centrifugation at $1,000 \times \mathrm{g}$ for $5 \mathrm{~min}$ at room temperature, and then they were resuspended in $25 \mathrm{mM}$ sodium phosphate buffer ( $\mathrm{pH} 7.0$ ) that contained $0.5 \mathrm{M}$ mannitol (about $2.5 \times 10^{9} \mathrm{cells} / \mathrm{ml}$ ). One portion of the suspension was mixed with 8.5 parts $(\mathrm{v} / \mathrm{v})$ of the solution of the enzymes, and then the mixture was incubated at $30^{\circ} \mathrm{C}$ for $3 \mathrm{~h}$ in the dark with shaking at $50 \mathrm{rpm}$ on a reciprocal shaker (model WB-III; TAIYO, Tokyo, Japan). The formation of protoplasts was estimated by addition of $0.1 \mathrm{ml}$ of the suspension to $2.9 \mathrm{ml}$ of distilled water and counting the unburst cells in a Thoma hemacytometer. To more sensitively detect cells with damaged cell walls, $0.1 \mathrm{ml}$ of the suspension was mixed with $2.9 \mathrm{ml}$ of $2 \%(\mathrm{w} / \mathrm{v})$ sodium dodecyl sulfate (SDS). In the present paper, the osmotically-labile cells and SDS-sensitive cells were defined as spheroplasts and protoplasts, respectively.

Preparation of protoplasts of $C$. vulgaris $\mathrm{C}-27$ was carried out according to the method of Hatano et al. (1992).

\section{Fluorescence microscopy}

The formation of protoplasts was also revealed by staining the cell wall with fluorescent brightner 28 (FB28; Sigma Chemicals Co.) as described below. Chlorella cells, which had been treated with the enzymes, were collected by centrifugation at $800 \times$ $\mathrm{g}$ for $5 \mathrm{~min}$. The cells were washed three times with $25 \mathrm{mM}$ sodium phosphate buffer $(\mathrm{pH}$ 7.0) containing $0.5 \mathrm{M}$ mannitol. Then, the cells were suspended in $0.05 \% \mathrm{FB} 28$ in the above buffer and stained under dark for $10 \mathrm{~min}$. After staining, the cells were washed four times with the above buffer, and then observed with a fluorescence microscope (Nikon 
Optiphot, dichroic mirror (DM400), excitation: 330 to $380 \mathrm{~nm}$, emission: $>420 \mathrm{~nm}$ )

\section{Regeneration of cell walls of protoplasts}

In order to restore protoplast to intact cells, regeneration of cell walls was tried. Protoplasts obtained from K-73122 and C-27 strains were collected by centrifugation at $800 \times \mathrm{g}$ for $5 \mathrm{~min}$ and washed three times with isotonic buffers, $20 \mathrm{mM}$ Tris-HCl buffer $(\mathrm{pH} 7.5)$ containing $0.5 \mathrm{M}$ mannitol, $0.8 \mathrm{M}$ mannitol, $0.4 \mathrm{M}$ sucrose or $0.5 \mathrm{M}$ sucrose to remove the enzymes. Washed protoplasts were resuspended in the same buffer at the concentration of about $10^{4}$ cells $/ \mathrm{ml}$. For regeneration of cell walls, PYG medium was used as a basic medium (Table 1). As listed in Table 3, $\mathrm{FeSO}_{4}$ or Fe-EDTA was used as iron source and agar, bacto-agar or agarose was added to PYG medium as the supporting. The protoplast suspension was diluted with the above buffers and the protoplasts were embedded in the regeneration media listed in the Table 4. Regeneration rates were calculated as follows: regeneration rate $(\%)=(A-B) /(C \times$ factor $-B) \times 100$, where factor $=\mathrm{D} / \mathrm{E}, \mathrm{A}$ : colony forming units $(\mathrm{cfu})$ of regeneration cells from protoplasts, $\mathrm{B}$ : cfu of osmotically-stable cells treated with sterilized water after digestion with enzymes, C: cfu of cells without digestion with enzymes, D and E: the numbers of enzyme-digested and -undigested cells counted with a Thoma hemacytometer under a microscope, respectively.

Table 1. Composition of PYG medium

\begin{tabular}{ll}
\hline Contents & Concentration \\
\hline Proteose peptone & $1.0(\mathrm{~g} / \mathrm{l})$ \\
Glucose & 2.0 \\
Yeast extract & 2.0 \\
$\mathrm{KNO}_{3}$ & 0.25 \\
$\mathrm{~K}_{2} \mathrm{HPO}_{4}$ & 0.075 \\
$\mathrm{KH}_{2} \mathrm{PO}_{4}$ & 0.175 \\
$\mathrm{MgSO}_{4} \bullet 7 \mathrm{H}_{2} \mathrm{O}$ & 0.075 \\
$\mathrm{NaCl}_{\mathrm{CaCl}} \bullet 7 \mathrm{H}_{2} \mathrm{O}$ & 0.025 \\
$\mathrm{FeSO}_{4} \bullet 7 \mathrm{H}_{2} \mathrm{O}$ or $\mathrm{Fe}-\mathrm{EDTA}$ & 0.01 \\
$\mathrm{H}_{3} \mathrm{BO}_{4}$ & $10.0 \mathrm{or} 15.0(\mathrm{mg} / \mathrm{l})$ \\
$\mathrm{MnCl}_{2} \bullet 4 \mathrm{H}_{2} \mathrm{O}$ & 2.9 \\
$\mathrm{ZnSO}_{4} \bullet 7 \mathrm{H}_{2} \mathrm{O}$ & 1.81 \\
$\mathrm{CuSO}_{4} \bullet 7 \mathrm{H}_{2} \mathrm{O}$ & 0.22 \\
$\left(\mathrm{NH}_{4}\right)_{3} \mathrm{Mo}_{7} \mathrm{O}_{24} \bullet 4 \mathrm{H}_{2} \mathrm{O}$ & 0.08 \\
$\mathrm{H}_{2} \mathrm{SO}_{4}$ & 0.018 \\
\hline
\end{tabular}

pH was adjusted to 6.5 with $\mathrm{NaOH}$.

\section{RESULTS AND DISCUSSION}

\section{Frequency of protoplasts formation of Chlorella vulgaris K-73122}

In attempts to prepare protoplasts of Chlorella, three characteristics were reported; 
it is necessary to keep isotonic buffer concentrations high compared to isotonic buffers for higher plants (Gobel and Aach, 1985); high concentration of cellulase is necessary for preparation of protoplast of Chlorella; hemicellulase specifically works well in preparation of protoplast of Chlorella though it is not effective in protoplast formation of higher plants (Rosen et al., 1985). Furthermore, rotifer eats Chlorella (Hirayama and Nakamura, 1976) and has enzymes, which digest cell walls of Chlorella, in its digestive organs (Chun et al., 1997). Chlorella itself also has cell-wall-lytic enzymes for division of cells (Hatano et al., 1992). Based on these reports, we started to develop a preparation method of protoplasts of Chlorella vulgaris K-73122.

For preparation of protoplasts of Chlorella vulgaris $\mathrm{K}-73122$, algal cells at the $\mathrm{L}_{2}$ stage were treated for $3 \mathrm{~h}$ with various combinations of $\mathrm{Ac}, \mathrm{Ce}, \mathrm{Ch}, \mathrm{Cl}, \mathrm{Gl}, \mathrm{Pe}, \mathrm{Us}$, the lytic enzyme in Chlorella homogenate, and the lytic enzyme in rotifer homogenate (Table 2).

Table 2. Effects of enzymes on production of SDS-sensitive and osmotically-labile cells of C. vulgaris $\mathrm{K}-73122$

\begin{tabular}{|c|c|c|}
\hline \multirow{2}{*}{ Enzyme } & \multicolumn{2}{|c|}{ Percent of cells } \\
\hline & SDS-sensitive & Osmotically-labile \\
\hline $\mathrm{K}-22 \mathrm{H}+$ rotifer $\mathrm{H}+\mathrm{Ce}+\mathrm{Ch}$ & 31 & 27 \\
\hline rotifer $\mathrm{H}+\mathrm{Ce}+\mathrm{Ch}$ & 87 & 57 \\
\hline $\mathrm{K}-22 \mathrm{H} \quad+\mathrm{Ce}+\mathrm{Ch}$ & 46 & 34 \\
\hline $\mathrm{K}-22 \mathrm{H}+$ rotifer $\mathrm{H}+\mathrm{Ch}$ & 47 & 17 \\
\hline $\mathrm{K}-22 \mathrm{H}+$ rotifer $\mathrm{H}+\mathrm{Ce}$ & 36 & 32 \\
\hline rotifer $\mathrm{H}+\mathrm{Ce}+\mathrm{Ch}+\mathrm{Ac}$ & 98 & 72 \\
\hline rotifer $\mathrm{H}+\mathrm{Ce}+\mathrm{Ch}+\mathrm{Us}$ & 92 & 68 \\
\hline rotifer $\mathrm{H}+\mathrm{Ce}+\mathrm{Ch}+\mathrm{Ac}+\mathrm{He}$ & 99 & 72 \\
\hline rotifer $\mathrm{H}+\mathrm{Ce}+\mathrm{Ch}+\mathrm{Ac}+\mathrm{Us}$ & 95 & 87 \\
\hline rotifer $\mathrm{H}+\mathrm{Ce}+\mathrm{Ch}+\mathrm{Ac}+\mathrm{Us}+\mathrm{Cl}$ & 92 & 45 \\
\hline rotifer $\mathrm{H}+\mathrm{Ce}+\mathrm{Ch}+\mathrm{Ac}+\mathrm{Us}+\mathrm{Gl}$ & 91 & 82 \\
\hline rotifer $\mathrm{H}+\mathrm{Ce}+\mathrm{Ch}+\mathrm{Ac}+\mathrm{Us}+\mathrm{Pe}$ & 92 & 50 \\
\hline $\mathrm{Ce}+\mathrm{Ch}+\mathrm{Ac}+\mathrm{Us}+\mathrm{Gl}$ & 100 & 88 \\
\hline
\end{tabular}

Cells were treated with the enzymes for $3 \mathrm{~h}$ at $30^{\circ} \mathrm{C}$.

K-22 H: K-73122 homogenate.

At first, we tried $\mathrm{Ce}, \mathrm{Ch}$, and $\mathrm{K}-73122$ homogenate or rotifer homogenate. For identification of protoplasts and spheroplasts, we counted numbers of osmotically-labile cells and SDS-sensitive cells, respectively. The results showed that the combination of the three enzymes converted only $17 \%$ to $57 \%$ of the cells into osmotically-labile cells. Especially, K-73122 homogenate did not contribute to spheroplast or protoplast formation, thus, the homogenate was thought to be unnecessary for protoplast formation. Next, the treatment with [the rotifer homogenate, Ce, and $\mathrm{Ch}$ ] converted $87 \%$ of the cells into SDS-sensitive cells. For high efficiency of protoplast formation, effects of addition of the other enzymes to the mixture of [the rotifer homogenate, $\mathrm{Ce}$, and $\mathrm{Ch}$ ] were investigated. Therefore, we examined Ac, He, and Us as an additional enzyme, one by one. When either Ac or Us was used, the efficiency of protoplast formation was enhanced: the additional use of Ac converted $98 \%$ of the cells into SDS-sensitive and $72 \%$ of the cells into osmotically-labile. The use of Us converted $92 \%$ of the cells into SDS-sensitive and 
$68 \%$ of the cells into osmotically-labile. When only Ac or both Ac and He were added, the efficiencies of protoplast formation were not different, suggesting that He was not necessary for protoplast formation. Furthermore, the additional use of both Ac and Us converted $95 \%$ of the cells into SDS-sensitive and $87 \%$ of the cells into osmotically-labile. For further good efficiency of protoplast formation, the effects of additional enzymes, $\mathrm{Cl}$, Gl or Pe, were studied. Out of the three enzymes, Gl was the most effective for the formation of protoplasts. On the other hand, whereas the rotifer homogenate occasionally contributed to the formation of protoplasts, the activity of the lytic enzymes in the rotifer homogenate was dependent on the lot of rotifer (data not shown). Hence, we decided not to use the rotifer homogenate. The treatment with [Ce, Ch, Ac, Us, and Gl] converted $100 \%$ of the cells into SDS-sensitive and $88 \%$ of the cells into osmotically-labile. The method of rapid preparation of protoplasts of Chlorella vulgaris K-73122 was established without the rotifer homogenate.

In order to confirm digestion of cell walls of $C$. vulgaris $\mathrm{K}-73122$, fluorescence microscopy was done. The results showed that the number of cells, whose cell walls were stained with fluorescent brightner 28 to light blue, decreased with the treatment time (Fig. 1). After $3 \mathrm{~h}$ of the treatment, cell walls stained with fluorescent brightner could not

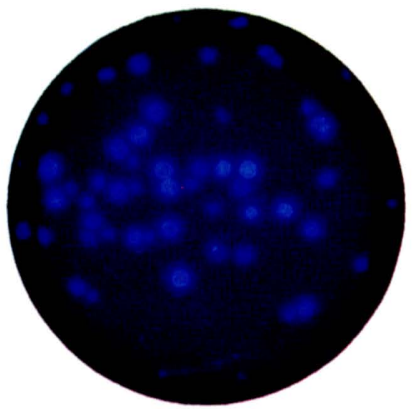

$\mathbf{0 ~ h}$

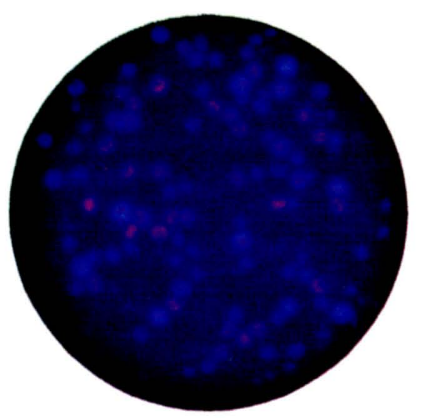

$2 \mathbf{h}$

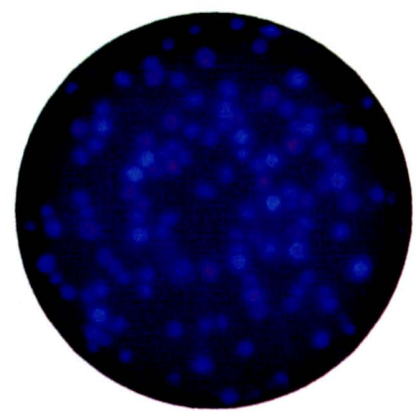

$1 \mathrm{~h}$

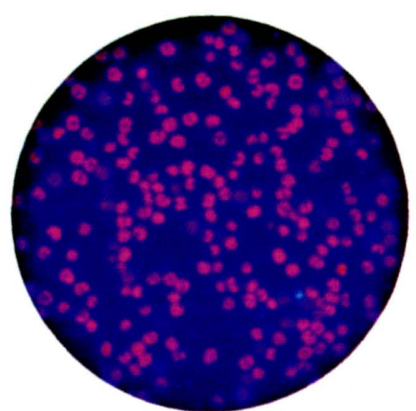

$3 \mathbf{h}$

Fig. 1. Fluorescent microphotographs of C. vulgaris $\mathrm{K}-73122$ after 0, 1, 2, and 3-h enzyme digestion. 
be seen and cells showed red fluorescence based on the chloroplast. The result showed that 3-h treatment of the cells led to almost complete digestion of the cell walls.

The cell-wall composition of Chlorella cells dynamically changes during the growth of the cells (Loos and Meindl, 1982). As shown previously (Hatano et al., 1992; Loos and Meindl, 1984), use of endogenous cell-wall-lytic enzymes was thought to be effective for preparation of protoplasts. Although the $\mathrm{C}-27$ homogenate containing the cell-wall-lytic enzymes contributed to the preparation of protoplasts of $C$. vulgaris C-27 (Hatano et al., 1992), K-73122 homogenate did not work in the preparation of protoplasts in the present paper. The homogenates should contain lytic enzymes necessary for cell division. However, the enzymes usually work from inside of the cells and probably digest only some parts of the cell walls. Thus, the homogenate might not work in vitro owing to their attack to the cell wall from outside of the cells.

\section{Regeneration rates of cell walls of protoplasts}

For regeneration of cell walls of $C$. vulgaris $\mathrm{C}-27$ and $\mathrm{K}-73122$, various conditions were examined. PYG medium was used as a basic medium (Table 1), and effects of supporting media and iron sources on regeneration of cell walls were investigated. Fe-EDTA was reported to be better than $\mathrm{FeSO}_{4}$ as an iron source for growth of Chlorella (Myers, 1951; Leone, 1963). Generally, agarose have been used as a supporting medium for growth of higher plants (Shimamoto et al., 1989; Wardrop et al., 1996). In the present paper, we compared three kinds of supporting media (agar, agarose, and bacto-agar). Hence, we investigated the efficiency of combinations of supporting media and iron sources for the regeneration of protoplasts into intact cells. The result showed that Fe-EDTA clearly improved regeneration rates of cell walls of protoplasts of C-27 strain compared to $\mathrm{FeSO}_{4}$ (Table 3). Especially, the combination of bacto-agar and Fe-EDTA led to a good regeneration rate $(37.2 \%)$. In the case of $\mathrm{K}-73122$ strain, the regeneration rate was also improved although the rate was low (4.2\%). So, the combination of Fe-EDTA and bacto-agar was used for further experiments.

Table 3. Regeneration of $C$. vulgaris $\mathrm{C}-27$ and $\mathrm{K}-73122$ protoplasts

\begin{tabular}{cllc}
\hline Strain & \multicolumn{1}{c}{$\mathrm{Fe}$} & \multicolumn{1}{c}{ Agar } & Regeneration rate (\%) \\
\hline C. vulgaris C-27 & $\mathrm{FeSO}_{4}$ & $0.4 \%$ Agar & 6.6 \\
& & $0.4 \%$ Agarose & 2.1 \\
& & $0.6 \%$ Bacto-Agar & 8.2 \\
& Fe-EDTA & $0.4 \%$ Agar & 29.2 \\
& & $0.4 \%$ Agarose & 0 \\
& & $0.6 \%$ Bacto-Agar & 37.2 \\
C. vulgaris $\mathrm{K}-73122$ & $\mathrm{FeSO}_{4}$ & $0.4 \%$ Agar & 0.5 \\
& & $0.4 \%$ Agarose & 0 \\
& & $0.6 \%$ Bacto-Agar & 0.2 \\
& $\mathrm{Fe}$ & $0.4 \%$ Agar & 2.4 \\
& & $0.4 \%$ Agarose & 0.8 \\
& & $0.6 \%$ Bacto-Agar & 4.2 \\
\hline
\end{tabular}

Regeneration rate was calculated as described in Materials and Methods. 
Table 4. Effects of mannitol and sucrose in buffers used for preparation and washing of protoplasts of $C$. vulgaris $\mathrm{C}-27$ and $\mathrm{K}-73122$ on regeneration of protoplast cells

\begin{tabular}{ccc}
\hline & \multicolumn{3}{c}{ Regeneration rate (\%) } \\
\cline { 2 - 3 } Sugar concentration & \multicolumn{3}{c}{ Strains } & K-73122 \\
\hline 0.5 M mannitol & 37.2 & 4.2 \\
0.8 M mannitol & - & 13 \\
0.4 M sucrose & 27.5 & 5.1 \\
0.5 M sucrose & 40 & 31.7 \\
\hline
\end{tabular}

Regeneration rate was calculated as described in Materials and Methods.

For better efficiency of regeneration of cell walls of protoplasts, conditions of preparing and washing protoplasts were also studied (Table 4). We examined mannitol and sucrose as an osmoticum, which maintains the osmolarity during preparation of protoplasts and washing cells. In both strains, sucrose was found to work as a good osmoticum. Especially, 31.7\% of protoplasts of the strain K-73122 showed colony-forming ability when $0.5 \mathrm{M}$ sucrose was used as an osmoticum. In the case of the strain C-27, using $0.5 \mathrm{M}$ sucrose also improved the regeneration rate up to 40\%. Abo-Shady (1990) used PEG1500 as an isotonic stabilizer for regeneration of cell walls of Chlorella. We tried to use PEG1500 for regeneration of cell walls of $C$. vulgaris $\mathrm{K}-73122$ and $\mathrm{C}-27$, but the both strains could not form colonies. Thus, sugars, such as sucrose, would be adequate as osmotica for regeneration of cell walls of both strains.

Agars as supporting media are known to contain inorganic matter including calcium salts. Bacto-agar showed best efficiency of regeneration of cell walls and agar showed better efficiency than agarose. This order is conversely proportional to the purification order of agars. For good efficiency of regeneration of cell walls, some impurities seem to be necessary or effective for regeneration of cell walls of protoplasts.

In the case of iron sources, Fe-EDTA showed better efficiency than $\mathrm{FeSO}_{4}$ (Table 3). Under neutral or basic $\mathrm{pH}, \mathrm{Fe}$ ion tends to form insoluble matter, which are difficult to be transported into cells (Oh-hama and Miyachi, 1988). Thus, because chelating agent EDTA keeps Fe ions soluble, Fe ions could be supplied to protoplasts for effective regeneration of cell walls of Chlorella.

Comparison of two types of osmotica, mannitol and sucrose, was done. The results showed that $0.5 \mathrm{M}$ sucrose, compared to mannitol, contributed to much efficient regeneration of cell walls of the protoplasts. Generally, plant cells have facility for incorporation of both sucrose and mannitol (Salmon et al., 1995). However, in Chlorella cells, there might be differences in the incorporation rate of mannitol and sucrose. Thus, differences in regulation of osmolarity would affect the regeneration rate of cell walls of the protoplasts.

This report showed the preparation of protoplasts of Chlorella vulgaris K-73122 and regeneration of cell walls of $C$. vulgaris strains, $\mathrm{K}-73122$ and $\mathrm{C}-27$. These approaches could underlie genetic modification of Chlorella for future technology. 


\section{REFERENCES}

Aach, H. G., S. Bartsch, and V. Feyen 1978 Studies on Chlorella protoplasts. Demonstration of the protoplastic nature and the regeneration of the cell wall. Planta, 139: 257-260

Abo-Shady, A. M. 1990 Somatic hybridization in green algae. Beitr. Biol. Pflanzen, 65: 409-418

Atkinson, A. W. Jr., B. E. S. Gunning, and P. C. L. John 1972 Sporopollenin in the cell wall of Chlorella and other algae: ultrastructure, chemistry, and incorporation of ${ }^{14} \mathrm{C}$-acetate, studied in synchronous cultures. Planta, 107: 1-32

Blumreisinger, M., D. Meindl, and E. Loose 1983 Cell wall composition of chlorococcal algae. Phytochemistrry, 22: 1603-1604

Chen, Y., Y. Wang, Y. Sun, L. Zhang, and W. Li 2001 Highly efficient expression of rabbit neutrophil peptide-1 gene in Chlorella ellipsoidea cells. Curr.Genet., 39: 365-370

Chun, C. Z., S. B. Hur, and Y. T. Kim 1997 Purification and characterization of an endoglucanase from the marine rotifer Brachionus plicatilis. Biochem. Mol. Biol. Int., 43: 241-249

Gobel, E. and H. G. Aach 1985 Studies of chlorella protoplasts. 2. Isolation and fusion of protoplasts from Chlorella Saccharophila (Kruger) Nadson strain 211-1A. Plant Sci., 39: 213-218

Hatano, S., T. Joh, T. Miyamoto, and M. Yoshimoto 1992 Preparation of protoplasts from Chlorella ellipsoidea C-27. Plant Cell Physiol., 33: 651-655

Hatano, S., H. Sadakane, M. Tutumi, and T. Watanabe 1976 Studies on frost hardiness in Chlorella ellipsoidea I. Development of frost hardiness of Chlorella ellipsoidea in synchronous culture. Plant Cell Physiol., 17: 451-457

Hawkins, R. L. and M. Nakamura 1999 Expression of human growth hormone by eukaryotic alga, Chlorella. Curr. Microbiol., 38: 335-341

Hirayama, K. and K. Nakamura 1976 Fundamental studies on the physiology of rotifers in mass culture-V. Dry Chlorella powder as a food for rotifers. Aquaculture, 8: 301-307

Leone, D. E. 1963 Growth of Chlorella pyrenoidosa in recycled medium. Appl. Microbiol., 11: $427-429$

Loos, E. and D. Meindl 1984 Cell wall lytic activity in Chlorella fusca. Planta, 160: 357-362

Loos, E. and D. Meindl 1982 Composition of the cell-wall of Chlorella fusca. Planta, 156: 270-273

Morita, K., M. Ogata, and T. Hasegawa 2001 Chlorophyll derived from Chlorella inhibits dioxin absorption from the gastrointestinal tract and accelerates dioxin excretion in rats. Environ. Health Perspect., 109: 289-294

Morita, K., T. Matsueda, T. lida, and T. Hasegawa 1999 Chlorella accelerates dioxin excretion in rats. $J$. Nutr., 129: 1731-1736

Myers, J. 1951 On the mass culture of algae. Plant Physiol., 26: 539-548

Noda, K., N. Ohon, K. Tanaka, N. Kamiya, M. Okuda, T. Yadomae, K. Nomoto, and Y. Shoyama 1996 A water-soluble antitumor glycoprotein from Chlorella vulgaris. Plant Med., 62: 423-426

Oh-hama, T. and S. Miyachi, 1988 Chlorella. In "Micro-algal Biotechnology" ed by Borowitzka, M. A. and Borowitzka, L. J., Cambridge University Press, New York, pp. 3-26

Rosen, B. H., M. D. Berliner, and M. J. Petro 1985 Protoplast induction in Chlorella pyrenoidosa. Plant Science, 41: 23-30

Salmon, S., R. Lemoine, A. Jamai, S. Bouché-Pillon, and F. Christophe 1995 Study of sucrose and mannitol transport in plasma-membrane vesicles from phloem and non-phloem tissues of cerely (Apium gravenolens L.) petioles. Planta, 197: 76-83

Shimamoto, K., R. Terada, T. Izawa, and H. Fujimoto 1989 Fertile transgenic rice plants regenerated from transformed protoplasts. Nature, 338: 274-276

Takeda, H. 1991 Sugar composition of the cell wall and thee taxonomy of Chlorella (Chlorophyceae). $J$. Phycol., 27: 224-232

Takeda, H. 1988 Classification of Chlorella strains by cell wall sugar composition. Phytochemistry, 27: 3823-3826

Takeda, H. and T. Hirokawa 1984 Studies on thee cell wall of Chlorella V. Composition of thee cell wall chemical compositions in strains of Chlorella ellipsoidea. Plant Cell Physiol., 25: 287-295

Watanabe, A. 1960 List of alga strains in collection at the Institute of Applied Microbiology, University of Tokyo. J. Gen. Appl. Microbiol., 6: 283-292

Wardrop, J., K. Lowe, J. B. Power, and M. R. Davey 1996 Perfluorochemicals and plant biotechnology: an 
improved protocol for protoplast culture and plant regeneration in rice (Oryza sativa L.). J. Biotechnol., 50: 47-54

Yamada, T. and K. Sakaguchi 1981 Protoplast induction in Chlorella species. Agric. Biol.Chem., 45: 1905-1909

Yamada, K., R. Moriyama, and S. Hatano 1987 Production of osmotically labile cells in Chlorella ellipsoidea C-27 and C-102 by enzyme treatment. Agric. Biol. Chem., 51: 579-580 